\title{
STANDARDIZED DEVELOPMENT OBJECTS RECONSTRUCTION IN DIFFICULT GEOCLIMATIC CONDITIONS
}

\author{
Timur Valerievich Radionov \\ Donbas National Academy of Civil Engineering and Architecture, \\ Derzhavin str. 2, 86123 Makiyivka, Ukraine \\ E-mail timur.radionov@mail.ru
}

Received 30 December 2013; accepted 08 April 2014

\begin{abstract}
In the article the strategic reconstruction issues of standardized development objects that are in the difficult geo-climatic conditions are examined. The solution of such issues depends on the demographic, social and economic position of the considered locality. During the research basic tasks were set that are aimed at the investigation of geological conditions of the area, the detailed analysis of the typological characteristics of buildings and structures that are undergoing the reconstruction as well as taking into account legislative environment of the project activities in this direction. Researches conducted, tasks set and recommendations developed have given the opportunity to present the main results of researches and to formulate definite conclusions. Scientific novelty of the research lies in the development of scientific and practical recommendations concerning the reconstruction of standardized development objects which are located in the difficult geoclimatic conditions.
\end{abstract}

Keywords: reconstruction, standardized development, urban development regulation, object, geotechnical conditions.

Reference to this paper should be made as follows: Radionov, T. V. 2014. Standardized development objects reconstruction in difficult geoclimatic conditions, Journal of Architecture and Urbanism 38(2): 142-147.

\section{Introduction}

Strategic goals and objectives of comfortable urban environment formation today are gaining more and more powerful and intense support from the population that lives in residential areas. According to N. F. Gulyanitskiy, L. I. Pavlova, V. A. Lavrov, G. E. Mishchenko, V. V. Vaisera - rational use of free architectural spaces and the systematic organization of architectural and urban systems can lead to ordering of urban areas that are exposed by a man and nature every day (Valentay 1975; Grossman 1967; Questions about the use of historical and cultural heritage in the urban renewal 1990; Pavlova 1994).

On the basis of the statements of the authors we can not agree with them completely as the problem of difficult geoclimatic conditions many cities of Donetsk region stay in can not be solved only by means of organization of architectural and urban systems, according to M. O. Hauke and V. G. Grossman the possibility of simplifying service relations between industrial and res- idential areas should be taken into account (Grossman 1967; Haukke 1967) in the way it was introduced at the standardized development objects reconstruction and in the reconstruction conditions of cities themselves.

Basic pragmatic reasons preventing urban designing role of urban renewal with a large number of standardized objects in difficult geoclimatic conditions were also ascertained in the researches. V. Glazychev highlights the same reasons; he believes in the need to support the process of historical and cultural heritage preservation in order to save and reconstruct standardized housing (Mishchenko 1971).

We can agree with the approval of the author and amplify that the historical and cultural heritage preservation is the foundation of all the objects preservation that belong to both standardized and nonstandardized objects but is necessary to combine and combine the process of reconstruction of old buildings and the construction of new ones. Therefore, it becomes especially 
important firstly to study complex effect of geological and climatic characteristics on the formation of conditions of standardized development urban environment, and secondly the formation of new strategic approaches for assessing typological potential of urban space for the realization of the possibilities for increasing the comfort of living of the population in standardized buildings that undergo reconstruction. Examples of standardized development urban environment are shown in Table 1.

\section{Research object}

This article considers and analyzes the complex process of development and reconstruction of the main typological groups of buildings and structures in difficult geoclimatic conditions. It also touches upon methodological issues and tasks of the use, development and reconstruction of areas that have a large percentage of obsolescence and physical depreciation in standardized buildings and constructions. G. E. Mishchenko hypothesized in his work "The most important problems of urban renewal" that the reconstruction of the urban standardized development results in the changing architectural shape and silhouette of the city as a whole (Lavrov 1971). We have to agree with the formulated hypothesis completely as, to date, the process of standardized development reconstruction ignores originally projected trends in the development of architecture and virtually destroys the historical and cultural heritage of urban standardized development that are in difficult geoclimatic conditions. To solve such problems, the basic tasks were set in the process of research; they are based on the writings of scientists as A. M. Pleshkanovskaya, E. D. Bogorod, E. B. Sokolova who were engaged in this direction:

1. Standardized development regularity analysis and social infrastructure development of densely populated territories in difficult geoclimatic conditions.

2. Analysis of the standardized objects location in the structure of the urban areas development.

3. Systematization of regulatory requirements for the reconstruction and modernization of standardized buildings and constructions located in difficult geological and climatic conditions (State building norms of Ukraine: Engineering protection of territories, buildings and structures on the bars and landslides 1998 ).

As a result of research tasks generalization, one comprehensive typological problem was singled out the problem of creation of more rational territorial structure of production and settlement. It is imple-
Table 1. Examples of general town planning schemes with complex reconstruction of urban areas that are in unfavorable geological conditions

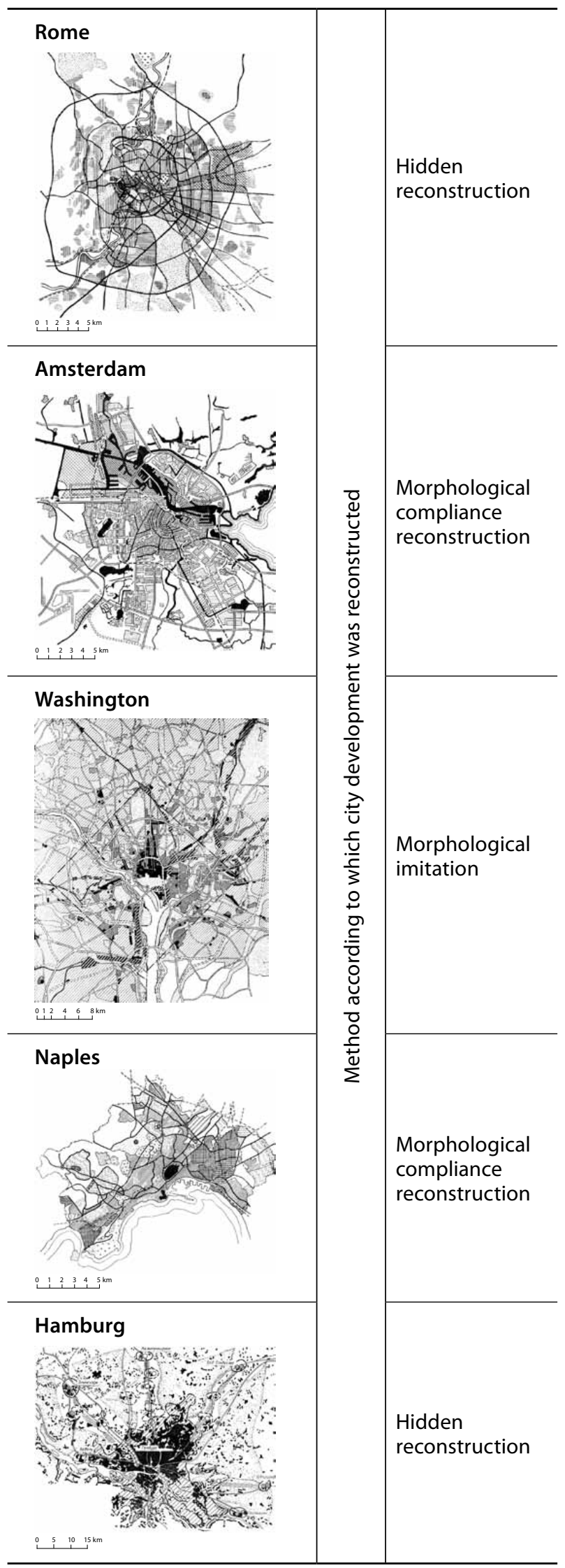


mented in three directions: 1) the accelerated development of the less developed districts, 2) accelerated development of small and medium-sized cities with the most favorable conditions for industrial construction, 3) equalization of economic development levels of different typological territorial units (up to lower administrative districts) for creating a single and close to it standard of the population living. It is very important that a complex solution of the problem is linked to a number of aspects of the spatial organization of the geographic environment in general. It should be borne in mind that urban population is rapidly growing in Ukraine and Donbass cities (Vaisera 1976; Questions about the use of historical and cultural heritage in the urban renewal 1990; Haukke 1967). O. K. Kudriavtsev and D. I. Valentay proved in their studies that the demography of the urban population plays a key role in the settlement systems formation, and consequently is directly related to the reconstruction of standardized development objects in which these populations groups reside. According to the results of studies of N. F. Gulyanitsky it is necessary to perform compositional analysis of urban structure that allows to explain the scientific value of the complex reconstruction of standardized development when reconstructing the objects of standardized development and working out new master plans combining standardized and new development. It should be also noted that at the stage of preproject investigations in the case of complex and strategic reconstruction it is necessary to consider and examine the expediency of the construction of separate buildings and building complexes on the areas selected for development located in the urban development structure (Kudryavtsev 1985).

The researches find that under current conditions people ceased to make demands on the reconstruction of standardized development objects regardless of their functional purpose: technical - protection of premises from the effects of the external environment, sufficient strength and durability; fire-prevention - providing opportunities of premises structural elements to maintain barrier and bearing capacity in case of fire; aesthetic - formation of the external appearance of the building (Vaisera 1976). Especially these demands are not taken into account today by the reconstruction process in the context of new architectural solutions.

Scientific and practical researches on the reconstruction of standardized development helped to identify the fact that each object projected or reconstructed for the city - and in the first place civil objects - is a solution of certain town planning problems as well as an effect on the creation of new urban architectural situation.
According to G. Borenko, S. Regame, R. Garyaeva, we should first of all consider the impact of the projectible object on the environment. Any building and construction can not create loads to the air, underground structures and water. Increase in the development expansion, in solid, waterproof coatings on the surface of urban areas can lead to critical loads and self-destruction of ecological system due to which the situation in the geoclimatic sphere can also deteriorate. The authors' statements are scientific and practical which we must agree with and add that urban population compaction leads to road network density increase and increase of the number of units of the automobile and electrical transport that affects the climate fluctuations of the populated area (Lasarev 2007; Sinyanskiy 2006).

\section{Research results}

The research finds that the rapid development of underground space in densely built-up areas with standardized buildings is closely linked to the issue of protection of buildings and structures that are affected by mining; it is not always possible to solve this problem by demolishing or bypassing buildings. The strongest and systematic deformation perturbations reaching the earth's surface form a movement or subsidence trough to which structures may get that are of industrial or historical value in their turn and as a rule - a standardized development objects.

It is established that comprehensive preservation of such objects is impossible without a reliable forecast of movements occurring at the Earth's surface. Existing to date methods of predictive calculation of movements for deep-level tunnels do not consider many mining and geological factors affecting the level of deformation perturbations and their results do not agree well with the field data. Statictical characteristic of the obsolescence and physical depreciation level of the standardized development objects that are in difficult geoclimatic conditions we can see in Table 2 (State building norms of Ukraine: Engineering protection of territories, buildings and structures on the bars and landslides 1998).

Table 2. Statictical characteristic of the obsolescence and physical depreciation level of the standardized development objects that are in difficult geoclimatic conditions

\begin{tabular}{llll}
\hline No & Object type & $\begin{array}{l}\text { Useful life, } \\
\text { years }\end{array}$ & $\begin{array}{l}\text { Depreciation } \\
\text { rate }\end{array}$ \\
\hline 1 & Public facilities & 30 & $80 \%$ \\
\hline 2 & Residential buildings & $40-50$ & $90 \%$ \\
\hline 3 & Industrial buildings & $30-40$ & $70 \%$ \\
\hline 4 & Farm buildings & $40-50$ & $50-65 \%$ \\
\hline
\end{tabular}


Based on the following characteristics it should be noted that the most attackable are residential buildings which are located in the difficult geoclimatic conditions. This trend is caused by a number of the following problems:

1. Illegal reconstruction and redevelopment of residential apartments (reconstruction performed not by the developed project, in other words - the unauthorized activities of inhabitants);

2. Lack of long-term planning of the possibility of such objects reconstruction both regionally and at the national level;

3. Ignoring the requirements of legal documentation during the use of residential buildings and structures;

4. Changing the functional purpose of domestic architecture objects.

It is first investigated that geoclimatic and anthropogenic processes affect not only the buildings and constructions but also the underground utility system - electric and telephone cables, water and sewerage systems. These processes in an industrial region are very often reflected in the architecture of towns and cities that has a negative and destructive impact on the architectural and planning organization of urban development and standardized architecture in general (Pryadko 2006).

Analysis of climatic and technological conditions in the cities of Donbas is presented at the first time taking into account the regulatory climate control and man-triggered conditions; it helped to identify the main and the most important conditions that should be considered in the process of standardized development objects reconstruction that is presented in Table 3 .

A. G. Lasarev asserts that exploring a range of problems concerning reconstruction of objects in difficult geoclimatic conditions it is not necessary to study and take into account the geological risk categories which are very relevant for cities with disturbed areas. Geological and hydrological risks are assessed as the possible social and economic losses in a city as a result of favorable processes development expressed in redu-

Table 3. The main conditions that should be considered in the process of standardized development objects reconstruction

\begin{tabular}{ll}
\hline Geological conditions & Anthropogenic conditions \\
\hline floods & derelict lands \\
\hline insolation & seismicity \\
\hline environmental conditions & soil properties \\
\hline ecological risks & climatic conditions \\
\hline karst cavities & ecological security \\
\hline
\end{tabular}

cing the stability of urban infrastructure and settlement system (Questions about the use of historical and cultural heritage in the urban renewal 1990).

Tasks in research, studied and analyzed sources, proposals and conclusions of authors such as N. F. Gulyanitsky, L. I. Pavlov, V. A. Lavrov, G. E. Mishchenko, V. V. Vaysera, O. K. Kudryavtseva, D. I. Valentay, A. M. Pleshkanovskaya, E. D. Bogorod, E. B. Sokolov and research and practice studies resulted in the first recommendations developed concerning the reconstruction of standardized development located in difficult geoclimatic conditions.

During full-fledged and complex reconstruction process of standardized buildings and constructions it is recommended to take into account:

1. Analysis of the standardized buildings redevelopment forms: (development of the main functions and parallel function, partial or complete transformation of buildings).

2. Architectural characteristics of the reconstructed object: (detailed investigation of buildings and structures, analysis of the data received in the course of investigation).

3. Technical and operational characteristics: (spatial planning and aesthetic characteristics of the building).

In order to prevent and eliminate the causes of future accidents in time during reconstruction in the process of planning the reconstruction of objects located in difficult geoclimatic conditions it is recommended:

1. To perform system analysis of graphical materials which allows determining the possibility of reconstruction realization of the project located in disturbed areas (Benai 2012 ).

2. By the reconstruction planning it is necessary to single out complex data related to the types of areas depending on their function.

3. To conduct a complex evaluation of the effectiveness of standardized development reconstruction that lies in the urban planning efficiency of complex reconstructive activities.

4. To calculate in advance the cost efficiency of the reconstructed object or objects group subject to price reduction of the design and construction activities which is shown in the Table 4.

Table 4. Percentage ratio of the reconstruction activities cost cheapening in relation to new construction

\begin{tabular}{lll}
\hline No & Type of work & Percentage ratio \\
\hline 1 & Partial reconstruction & $12 \%$ \\
\hline 2 & Full reconstruction & $21-34 \%$ \\
\hline 3 & Complex reconstruction & $34-50 \%$ \\
\hline
\end{tabular}


5. To learn, use and adjust the initial permission documentation for the reconstruction of the object located in the difficult geoclimatic conditions. In this case the initial permission documentation must include: well-grounded choice of the plot of land on which a new object will be located, architectural planning assignment for the construction or reconstruction, complex opinion letter concerning geological studies considering the presence of minerals, limits concentration data for the development of the draft of environment impact assessment, plot of land plan where the reconstructed object is situated with a catalog of coordinates, engineering services connection specifications as well as the resolution about the possibility of the object reconstruction (Questions about the use of historical and cultural heritage in the urban renewal 1990).

6. To perform analysis and monitoring of climatic and anthropogenic conditions that include wind flows, temperature rate, solar radiation, mechanical qualities of soils, precipitations, relief, noise, paculiarities of the water influence on anthropogenic soils - karst, ravines, floods, waterlogging, erosion of coasts, drains and reservoirs, avalanches, landslides, slide-rocks, anthropogenic soils, vibration, seismicity, environmental factors, radiation level, the level of pollution of water, soil, air, and all directly related factors that affect the structural and systematic change of climatic and geological conditions (Questions about the use of historical and cultural heritage in the urban renewal 1990; Krylova 2007) presented on the whole territory of Donbass and on the territory of all its engineering-geological districts shown in the Table 5.

Table 5. Scheme of the engineering and geological mapping of the Donetsk region

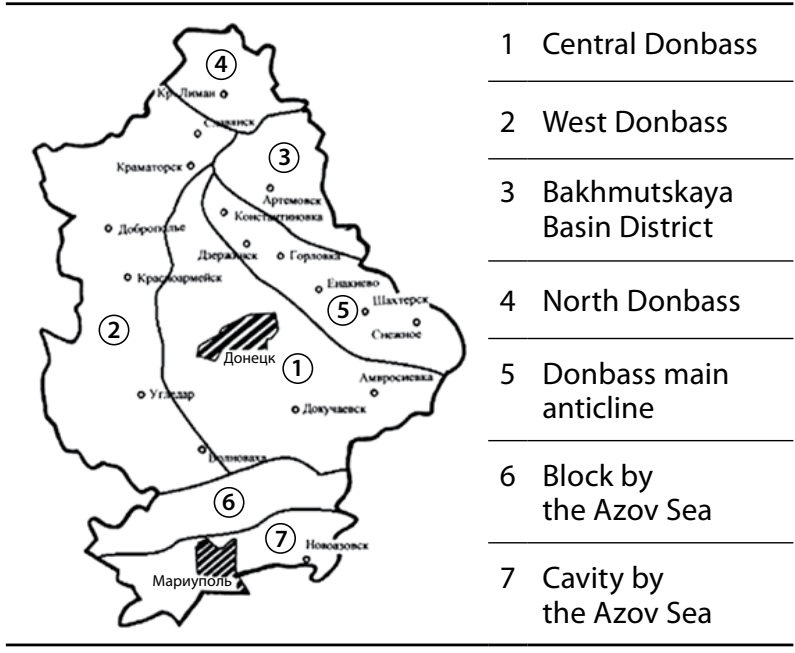

7. To elaborate detailed classification of typological structure of reconstructed area which includes counting groups of buildings, counting types of buildings, counting stories of buildings, the proportion of modern buildings to the standardized ones, the classification of existing buildings and structures.

8. To perform analysis of three-dimension spatial planning solusions of objects to be reconstructed: the configuration of the objects in the area, development density, the ensemble organization, the location of the focal point, forms coupling.

9. To perform detailed researches of the plumbing installation of buildings and structures: strategic water supply, complex sewerage, autonomous heating, complex lighting of buildings and structures, integrated cooling and power supply.

10. To take into account the complex elements forming construction ensemble: shape elements, completeness of buildings and constructions, complex colour solution, stylistic solutions, the use of modern materials.

P. Hill considers in his method of design the process of decision-making which is based on a detailed analysis of the initial data for design as an important condition. And the author is absolutely right since the design process begins with the design assignment which is accompanied with a detailed analysis of all output data.

\section{Conclusions}

1. Regularity of construction analysis and social infrastructure development of densely populated territories located in difficult geoclimatic conditions show that experts in architecture and engineering are trying in recent decades to develop integrated projects that include analysis and considering difficult geoclimatic conditions affecting the architectural and structural design of the buildings and structures. Complex procedural arrangements recommended for the performance of standardized development reconstruction projects include basic strategic and systematic solutions allowing removing defects of buildings, improving architectural and operational characteristics of buildings and giving constructive and technical reliability of structures in time.

2. Analysis of the standardized objects location in the structure of the urban areas development was effective in proving that procedural arrangements carried out in difficult geoclimatic conditions should include basic procedures for standardized development area reconstruction and development planning; they confirm that the standardized objects are the process of reorganization of the urban environment 
the content and duration of which are determined by the coordinated actions in design, planning and implementation of reconstruction activities.

3. Systematization of regulatory requirements for the reconstruction and modernization of standardized buildings and constructions located in difficult geological and climatic conditions ascertained and was helpful to prove that the regulatory process of reconstruction in difficult geoclimatic conditions should be conducted when planning the reconstruction and when it is necessary to assess the architectural and urban planning situation of the standardized development area including a preliminary estimate of the buildings compaction possibility taking into consideration the physical state and the moral degradation level of buildings (development) and the ratio of types of development in the architectural planning typological organization as well.

\section{References}

Benai, H. A. 2012. Problematika formirovanija centralnoj chasti slozhivshihsja gorodov (na primere centralnoj ploshhadiim. V. I. Lenina goroda Donecka) [Central part formation problems in existing cities (at the example of the Lenin Square in Donetsk)], H. A. Benai, O. S. Svetlichnaja, Problemi arhitekturi i mistobuduvannja [Problems of Architecture and Urban Planning], Visnik DONNABA 4(96): 67-72.

Derzhavni budivelni normi Ukraïni: Budinki i sporudi na pidrobljuvanih teritorijah i prosidajuchih gruntah: DBN V.1.1-5-2000. Vidannja oficijne [State building norms of Ukraine: Buildings and constructions on the anthropogenic areas and soil subsidence: DBN V.1.1-5-2000. Official issue]. 2000. Derzhavnij komitet Ukraïni z budivnictva ta arhitekturi [State Committee of Ukraine for Construction and Architecture and Housing Policy]. $63 \mathrm{~s}$.

Derzhavni budivelni normi Ukraïni: Inzhenernij zahist teritorij, budinkiv i sporud vid zasuviv ta obvaliv. Osnovni polozhennja: DBN V.1.1-3-97. Vidannja oficijne [State building norms of Ukraine: Engineering protection of territories, buildings and structures on the bars and landslides. Key provisions: DBN V.1.1-3-97. Official issue]. 1998. Derzhbud Ukraïni. $40 \mathrm{~s}$.

Grossman, V. G. 1967. Rekonstrukcija centra Berlina [Reconstruction of the centre of Berlin], V. G. Grossman, Rekonstrukcija gorodov (opyt zarubezhnyh stran) [Reconstruction of cities (experience of foreign countries)]. CNIIP gradostroitelstva [TSNIIP of urban planning], 68-74.

Haukke, M. O. 1967. Reshenie problemy rasselenija v praktike rekonstrukcii krupnyh gorodov zarubezhnyh stran [Solving the problem of settlement in practice of reconstruction in large cities abroad], Rekonstrukcija gorodov (opyt zarubezhnyh stran) [Reconstruction of cities (experience of foreign countries)]. CNIIP gradostroitestva [TSNIIP of urban planning]. 10-43.

Krilova, L. O. 2007. Donechchina. Suchasnij vimir. Kniga druga [Modern times. Book 2] z il. L. O. Krilova, L. I. Nazarova Doneck: Diaprint. $256 \mathrm{~s}$.

Kudriavtsev, O. K. 1985. Rasselenie i planirovochnaja struktura krupnyh gorodov-aglomeracij [Settlement and the planning system of metropolitan agglomeration]. Strojizdat, $136 \mathrm{~s}$.
Lavrov, V. A. 1971. Blizhajshie i perspektivnye zadachi rekonstrukcii gorodov [Immediate and long-term objectives of urban renewal], V. A. Lavrov, Razvitie i rekonstrukcija gorodov: Nauchno-tehnicheskij sbornik [Development and reconstruction of cities: Scientific and technical manual]. Budivelnik, 7-11.

Lazarev, A. G. 2007. Tehnologija proektirovanija grazhdanskih $z$ danij [Civil buildings designing technology]. Rostov n/D.: Feniks. $285 \mathrm{~s}$.

Mishhenko, G. E. 1971. Vazhnejshie problemy rekonstrukcii gorodov [The most important problems of cities reconstruction], E. G. Mishhenko, Razvitie i rekonstrukcija gorodov: Nauchno-tehnicheskij sbornik [Development and reconstruction of cities:Scientific and technical manual]. Budivelnik, 3-7.

Pavlova, L. I. 1994. Gorod. Modeli i realnost [The City. Models and reality]. Strojizdat. 320 s. ISBN 5-274-07763-5.

Prjadko, N. V. 2006. Obsledovanie i rekonstrukcija zhilyh zdanij. Uchebnoe posobie [Residential buildings investigation and reconstruction. Manual]. DonNASA. 156 s. ISBN 5-7763-0086-x.

Sinjanskij, I. A.; N. I. Maneshina. 2006. Tipologija zdanij i sooruzhenij [Maneshina. Buildings and constructions typology]. Akademija. $176 \mathrm{~s}$.

Valentay, D. I. 1975. Rost gorodov i sistema rasselenija [Cities Growth and settlement system]. Statistika, $112 \mathrm{~s}$.

Vajsera, V. V. 1976. Rol jetalona v upravlenii razvitiem gorodov i sistem naselennyh mest [The role of the standard in managing urban development and systems of populated areas], V. V. Vajsera, A. V. Kochetkov, O. V. Nosov-Beljakov, Regionalnoe rasselenie i rajonnaja planirovka [Regional settlement and planning]. CNIIP gradostroitelstva [TSNIIP of urban planning], 91-102.

Voprosy ispolzovanija istoriko-kulturnogo nasledija pri rekonstrukcii gorodov [Questions about the use of historical and cultural heritage in the urban renewal]. 1990. Vsesojuznyj nauchno-issledovatelskij institut teorii arhitektury i gradostroitelstva [All-Union Research Institute of Architecture and Urban Planning]. Vypusk 3 [Issue 3]. VNIITAG. $78 \mathrm{s.}$

\section{TIMUR VALERIEVICH RADIONOV}

Donbas National Academy of Civil Engineering and Architecture, Derzhavin str. 2, 86123 Makiyivka, Ukraine.

E-mail: timur.radionov@mail.ru

Timur Valerievich Radionov was born February 27, 1988 in Donetsk, Ukraine. 2005 - graduated from Donetsk multidisciplinary Lyceum, physical mathematic direction. 2005-2010 - studied at Donbas National Academy of Civil Engineering and Architecture at the architectural department in Makeevka (Ukraine). 2010-2011 - was trained in graduate Donbas National Academy of Civil Engineering and Architecture, and in 2011 graduated an architectural faculty with distinction and got qualification of master's degree of architecture of buildings and constructions. 2011 - was accepted on position of leading architect of enterprise on planning and reconstruction of buildings and constructions city Donetsk (Ukraine). 2011 - present time - is the graduate student of department of the architectural planning and design of architectural environment Donbas National Academy of Civil Engineering and Architecture.

Research interests: a comprehensive survey of typical building cities of Donbass, the problem of expanding the territory of the industrial metropolis. 